\title{
Term 'Household' in the Latvian Legal Framework
}

\author{
Lidija Rozentāle \\ ORCID: 0000-0001-5139-4642 \\ Rìga Stradiň̌ University, Latvia \\ Lidija.Rozentale@rsu.lv
}

\begin{abstract}
Originality / value - the content of this article - is based on the author's own original research. The study presents empirically tested arguments, interpretation of the term 'household' in the Latvian regulatory enactments. At a time when a state of emergency has been declared in the country, in such circumstances there is neither precise normative terminology, nor criteria for defining household. Those applying legislation have no uniform understanding as to whether a relationship established in a partnership can be viewed as household. This issue requires further research and discussion. The aim of the publication is to reveal some legal issues that directly affect couples living in a household.

Keywords: partnership, relationship, common household.

\section{Introduction}

The COVID-19 pandemic caused by coronavirus has shattered traditional lifestyle in Latvia. COVID-19 is a disease caused by newly discovered coronavirus SARS-CoV-2, which has been spreading around the world. The new coronavirus was detected in Wuhan, the capital of Hubei province in China, in January 2020, and more than one million COVID-19 cases were recorded as early as the beginning of April 2020 (Valsts Kanceleja, 2020). People all over the world faced restrictions on their rights, including the right to move freely, gather, do shopping, entertain, travel, etc.

Based on the data of Kantar's COVID-19 Barometer, the coronavirus-induced exceptional situation affected the daily lives of almost half (46\%) of Latvia's population (June - 38\%, August - 31\%); the biggest impact can be observed in young people aged 18-24 (Kantar, 2020). People encountered massive inconveniences, such as working from home, children's at-home learning, or inability to see relatives to spend holidays together.
\end{abstract}


The term 'household' has become prominent due to restrictions imposed over the COVID-19 spread and their regulation, which is why it is important to develop a uniform understanding and criteria for defining 'household' to be able to apply specific restrictions with no questions asked and solve matters relating to an individual's (administrative) liability. Before the pandemic, the term 'household' had been used primarily in the context of social assistance and social services, as well as concerning partnerships.

The aim of the article is to analyse the term 'household' used in laws dealing with measures introduced to curb the spread of COVID-19, also in the context of partnerships, and identify deficiencies in the laws and suggest potential solutions.

The following methods have been employed during the research: analytical method for exploring substance of laws dealing with the term 'household' and partnerships and for studying and analysing related literature and case-law; deductive method for making conclusions about findings and opinions of other authors. Legal interpretation has been also used for the purposes of the article. Grammatical interpretation is employed to understand the meaning of laws. Systematic method is used to compare laws as to understand the reasons for their adoption and their differences. The essence and spirit of and necessity for legal norms are analysed according to teleological method.

Legal framework relating to COVID-19-induced restrictive measures, publications of various authors and national legislation serve as the basis of the research.

\section{Discussion}

Many conditions concerning households, including the meaning of the term 'household', were discussed in the context of the pandemic and COVID-19-induced restrictions during LTV's show "4. studija" on 14 January 2021. The authors of the show consulted the Central Statistical Bureau (CSB) about the meaning of 'household' in statistics. According to a CSB's representative, there exist two approaches to define 'household'. First, it is "keeping house together". For example, when "several persons share the same apartment, buy food and often share their income, this is a family from a traditional point of view". Another explanation used for statistical purposes is "living together", which means that all people residing at the same address form a household (4. studija: LTV's show, 2021). Meanwhile, Dr. oec. M. Dunska, Associate Professor of the Faculty of Economics and Management of the University of Latvia, explains that "the use of 'household' is justified, it is a term used in statistics and demography, and economics. Regarding economics, it is used most frequently in macroeconomic analysis. In statistics, 'household' means a group of persons who live in the same dwelling and share expenditures, or a person living alone". According to the professor, the Dictionary of Economics and Finance contains a shorter definition of the term 'household', namely: a family consisting of one or several persons" (Dārziña, 2011). Based on the opinions of professionals representing different areas, the term 'household' can be explained as a group of persons living together in the same dwelling. However, considering that a 'household' may involve 
married couples, or couples living in a partnership, or persons who are related otherwise, it is essential to identify explanations provided by legislation.

Regulations of the Republic of Latvia Cabinet of Ministers No 360 on Epidemiological Safety Measures for the Containment of the Spread of COVID-19 Infection entered into force on 10 June 2020. In addition, a state of emergency was declared in Latvia on 9 November 2020 to curb the spread of COVID-19. A state of emergency is a special legal regime, during which the Cabinet of Ministers may restrict the rights and freedoms of authorities and natural and legal persons and impose additional duties on them in accordance with the procedure and to the extent defined by the law to prevent any threats to the country. Distancing is one of restrictive measures, and it means that a two-metre physical distance must be kept where possible, while people gatherings indoors and outdoors are allowed as follows:

1) not more than two persons;

2) persons living in one household;

3) a parent and his/her minor children if they do not live in one household.

This is one of restrictive measures provided by the Cabinet regulation with respect to persons living in a household, without explaining the term 'household' though. In view of the above, the author will check whether the term in question has already been defined in the existing legislation.

Article 1(40) of the Law on Social Services and Social Assistance defines the term 'household' as "several persons living in one dwelling and sharing expenditures, or one person living alone" (Saeima, 2002). M. Pavasare, Senior Assistant of the Division for the Organisation of Social Work and Social Assistance of the Department of Social Assistance and Social Services of the Ministry of Welfare, notes that "in this case, the determining criteria as per Latvian legislation are being a group of persons (regardless of whether they have family links with each other) and keeping a common household, i.e., persons live in the same dwelling and share living expenses" (Kupče, 2011). Social assistance is already provided in Latvia based on assessment of relationships among persons who in practice reside in a household, regardless of whether their relationships are registered formally, to ensure the most appropriate social assistance. Meanwhile, other laws and regulations indeed give priority to the legal status of relationships. For example, if a partner is taken to hospital, medical staff is not allowed to inform the other partner about the partner's health condition according to the Patients' Rights Law, or, if a partner dies, property matters cannot be solved.

Consequently, the term 'household' is explained in legislation, but there is yet no clear and comprehensive list of criteria for unequivocally defining persons who should be viewed as 'household'. Based on opinions provided by professionals in different areas, the term 'household' may still refer to persons whose relationships are not registered. This means that the term 'household' may cover not only family ties and relationships based on an officially registered marriage, but also non-official partnerships and other situations when persons share the same dwelling (for example, hostels). 


\section{Term 'Partnership'}

The terms 'household' and 'partnership', discussed above, are used in the context of restrictions imposed to curb the spread of COVID-19 and their regulation. For example, in situations when more than two persons share the same car to go to work, police officers are forced to detect whether the persons concerned form a family or are in a partnership or live in the same household. Meanwhile, the objective of the restrictive measures and their regulation is to halt the spread of the virus.

Substance of the partnership concept is unclear, and so is the interpretation of related terms: living together, trial marriage, consensual union, cohabitation, etc. The approach adopted for definition and practical recognition of partnerships in legislation and everyday language varies from country to country, considering historical development, recognition and occurrence of this phenomenon on a national scale and existence and objectives of legal framework. With a view to achieving a full understanding of the partnership concept, the author would like to identify social factors that facilitate cohabitation, such as solution of the housing problem, economic reasons, emotions. It is mentioned in the study "Comparative Analysis of Factors Affecting Registered and Nonregistered Cohabitation” (Latvijas Universitāte, Publiskās antropologijas centrs, 2015) that

\footnotetext{
"[...] the formation of a family has transformed from an arrangement to the dynamics of an individual relationship - intensification of the relationship, start of cohabitation, birth of a child - where the quality of the relationship has primary importance. A marriage does not necessarily form a part of the dynamics of this relationship, and it is not regarded as a factor impacting on the quality of the relationship. It is hard to pinpoint a set of factors that lead to the official registration of a relationship, but there are some common details in the experience of study participants suggesting that there are still impacts that can promote the evolution of a relationship into a marriage".
}

In the author's opinion, it is hardly possible to introduce a uniform definition of the term 'partnership' which could be accepted by all countries at an international level, and establish the legal status of this concept in laws. This is due to peculiarities of every country's historical development, culture and customs.

The following definition can be found in the European legislation: "Subjects of a non-registered partnership are two opposite-sex or same-sex partners who live in the same household and whose relationship is analogous to that between husband and wife" (Diduck, 2006). Accordingly, subjects of a non-registered partnership are: (1) heterosexual partners, (2) homosexual partners. This definition legitimises a set of indications of a family since emphasis is laid on cohabitation and relationship between partners as that of a married couple.

Article 6(2) of the Treaty on European Union sets forth that the Member States in applying European Union (EU) legislation must respect fundamental rights, including prohibition on discrimination on grounds of sexual orientation. Therefore, although the EU legislation does not provide for a Member State the duty to allow or recognise 
same-sex partnerships or marriages, the Member States applying EU legislation are still required to ensure equal treatment of same-sex couples and opposite-sex couples (including legislation on free movement, migration and asylum). To this end, the author suggests her definition of the term 'partnership' could be described as a long and stable relationship of two persons of the opposite sex or, in certain situations, of the same sex living together, whose goal is to establish a socially significant link between the partners and their relatives without registering a marriage.

Frequently, balancing different areas of life leads to a situation when persons are in a partnership but do not reside permanently in the same household; namely, each person has their own household, visiting the other person regularly. It should be concluded that there is no uniform mechanism in the case of partnerships for defining what should be set directly as the key criterion: existence of a relationship or sharing of the same dwelling. The state should ensure equal rights for all citizens, both taxpayers and members of society, in a democratic system, and that is why a political position that marriage between a woman and a man is the most appropriate type of relationships is not understandable. The question remains if two persons (either of the same sex or the opposite sex) form a relationship, why the registration of their relationship should be thrust upon them and whether this registration entails a duty to live together in the same household.

As can be inferred from the above, there are no clear criteria for determining a household either in the existing legislation or in application of the legislation in practice. Moreover, the following factual circumstances may make determining a household even more difficult:

1) a marriage has been registered but spouses live separately, i.e., they do not live together in the same 'household';

2) two persons (either of the same sex or the opposite sex) live together in the same 'household' but their marriage is not registered;

3) a regular partnership has been established and is maintained between two persons (either of the same sex or the opposite sex) who do not live together in the same 'household' and have not registered their marriage.

Considering the above, the application of provisions concerning administrative liability may be challenging, including demands of the restrictive measures introduced over COVID-19.

\section{Conclusions}

In view of the analysed legislation, the author concludes that the term 'household' is explained in the legislation, but there is yet no clear and comprehensive list of criteria for unequivocally defining persons who should be viewed as a 'household'. Therefore, it may also be hard to apply provisions concerning administrative liability regarding restrictive measures introduced over COVID-19. 
In the context of the COVID-19-induced restrictions, it can be concluded that siblings and their families, cousins or other relatives, usually regarded as a family, should not be treated as a household, which also refers to grown-up children visiting their parents, unless they live together constantly.

Based on the analysis of Latvian laws and opinions of professionals from different areas, the term 'household' may cover not only family ties and relationships that are officially registered as marriage, but also non-registered partnerships. In order to form an unambiguous understanding of the scope of the term 'household', the author offers her definition of 'partnership', which could be described as a long and stable relationship of two persons of the opposite sex or, in certain situations, of the same sex living together, whose goal is to establish a socially significant link between the partners and their relatives without registering a marriage. Moreover, there are two types of households according to Commission Implementing Regulation (EU) 2019/2181:

1) a person usually resides alone in a housing unit without the intention to be joined by another person to share income or expenses in order to provide the essentials of living for him/herself and his/her relative;

2) a group of two or more persons usually reside together in a housing unit and share income or expenses to provide the essentials of living for themselves and their relatives (several persons).

The term 'household' is characterised by the following: usual residing in a housing unit and economic considerations, which means that this term has no impact on the status of persons' relationships. As a result, the author offers the following criteria for defining 'household':

1) one person or small groups of persons;

2) usual residing in the same dwelling;

3) persons are free to choose where to reside;

4) independent decision-making about the division of their financial and other resources;

5) sharing of income, including movable and immovable properties;

6) joint consumption of certain goods and services, mainly those relating to food and the house.

\section{Bibliography}

\section{Legislation}

1. Commission Implementing Regulation (EU) 2019/2181. Official Journal of the European Union, 20.12.2019. https://eur-lex.europa.eu/legal-content/LV/TXT/HTML/?uri=CELEX:32019R2181 \&from=EN\#d1e138-16-1.

2. Republic of Latvia Cabinet Regulation No 360 of 9 June 2020 on Epidemiological Safety Measures for the Containment of the Spread of COVID-19 Infection. Latvijas Vēstnesis, 110B, 09.06.2020. https://likumi.lv/ta/id/315304.

3. Saeima. (2002). Law on Social Services and Social Assistance. Latvijas Vēstnesis, 168, 19.11.2002. https://likumi.lv/ta/id/68488. 


\section{Literature}

4. Dārziṇa, L. (24.02.2011). Kas ir mājsaimniecība? Un kāpēc tā nav ǵimene? LV portāls. https:// lvportals.lv/skaidrojumi/226277-kas-ir-majsaimnieciba-un-kapec-ta-nav-gimene-2011.

5. Diduck, A. (2006). Family law, gender and the state: text, cases and materials. Oxford: Hart Publishing, 2006. p.66.

6. European Union Agency for Fundamental Rights. (2009). Same-Sex Couples, Free Movement of EU Citizens, Migration and Asylum, https://fra.europa.eu/sites/default/files/fra_uploads/1225Factsheet-homophobia-couples-migration_EN.pdf

7. Kantar. (25.11.2020). Arvien vairāk Latvijas iedzīvotāju (46\%) izjūt koronavīrusa radītās situācijas ietekmi uz ikdienas dzīvi. https://www.kantar.lv/arvien-vairak-latvijas-iedzivotaju-46-izjutkoronavirusa-raditas-situacijas-ietekmi-uz-ikdienas-dzivi/.

8. Kupče, M. (04.04.2011). G̦imene un mājsaimniecība sociālā dienesta skatījumā. LV portāls, 04.04.2011. https://lvportals.lv/skaidrojumi/228124-gimene-un-majsaimnieciba-sociala-dienesta-skatijuma-2011.

9. Latvijas Universitāte, Publiskās antropologiijas centrs. (2015). Reǵistrētas un nereǵistrētas kopdzīves faktoru salīdzinoša analīze: Pētījuma ziṇojums, p.8. http://www.antropologija.lu.lv/ fileadmin/user_upload/lu_portal/projekti/antropologija/zinas/Petijums_kopdzive-2015.pdf. 10. Valsts kanceleja. (21.05.2020). Covid-19 izplatība pasaulē. https://covid19.gov.lv/covid-19-izplatiba-pasaule.

11. 4. studija: LTV raidījums. (14.01.2021). Ko nozīmē "viena mājsaimniecība"? https://www.lsm. lv/raksts/zinas/latvija/ko-nozime-viena-majsaimnieciba.a388828/. 